\title{
Inventarisasi jenis alat tangkap landak laut (sea urchin) di Pulau Tomia, Wakatobi
}

\author{
La Nane
}

*Jurusan Manajemen Sumber Daya Perairan, Fakultas Perikanan dan IImu Kelautan, Universitas Negeri Gorontalo. Email: lanane@ung.ac.id

\begin{abstract}
Landak laut Diadema setosum merupakan salah satu biota laut dari filum echinodermata yang seluruh permukaan tubuhnya ditutupi oleh duri. Duri yang dimiliki oleh $D$. setousum terdiri dari duri jalan dan duri beracun. Duri beracun ini digunakan sebagai salah satu alat pertahanan tubuhnya dari pemangsa atau predator. Di sisi lain, telur landak laut $D$. setosum kini semakin mulai digemari untuk penganan lokal. Akan tetapi, di beberapa tempat pemanfaatan landak laut belum dilakukan karena minimnya informasi tentang teknik penangkapan landak laut. Karena itu sangat dibutuhkan informasi tentang alat tangkap landak laut serta teknik pengoperasiannya. Tujuan penulisan artikel ini adalah untuk memberikan informasi kepada pembaca tentang jenis-jenis alat tangkap yang digunakan oleh nelayan dalam penangkapan landak laut $D$. setosum di Pulau Tomia, Kabupaten Wakatobi.
\end{abstract}

Keywords: Penangkapan; Landak Laut; Diadema setosum; Wakatobi

(c) (i) (9) (2)

How to cite: Nane, L. (2020,). Inventarisasi jenis alat tangkap landak laut (sea urchin) di Pulau Tomia, Wakatobi. Open Science for Fisheries, 1(1), 6-9. https://doi.org/10.31219/osf.io/u93en

\section{Introduction}

Telur landak laut Diadema setosum telah menjadi penganan primadona masyarakat di Pulau Tomia, Wakatobi (Nane, 2020; Nane \& Paramata, 2020). Telur D. setosum ini pada umumnya dikonsumsi secara segar (Baruadi \& Nane, 2020; Nane, 2019b) dan dimakan dengan penganan lokal berbahan ubi kayu yang telah dikukus yang dikenal secara lokal dengan nama kasoami. Selain itu, telur $D$. setosum juga dimakan dengan nasi. Pola konsumsi masyarakat terhadap telur $D$. setosum secara segar tersebut telah dilakukan sejak lama secara turun temurun dan telah menjadi budaya lokal dalam menyantap telur landak laut (Nane, 2019c, 2019a). Secara lokal landak laut $D$. setosum di Pulau Tomia dikenal dengan nama lokal nee mata-mata yang dalam Bahasa Indonesia berarti "landak laut bermata”.

Landak laut ini dikenal sebagai salah satu spesies yang memiliki racun pada durinya (Aprilia et al., 2012; Sukreni et al., 2018). Hidupnya ada yang soliter dan mengelompok (Lubis et al., 2017; Noviana et al., 2019) dan banyak ditemukan pada daerah baren di sekitar ekosistem padang lamun dan ekosistem terumbu karang. Racun tersebut tidak 
mematikan. Namun terasa cukup perih bila salah satu anggota badan kita tertusuk oleh durinya. Duri D. setosum ini mudah patah karena tersusun dari zat kapur (kalsium karbonat). Bagi masyarakat di Pulau Tomia, tertusuk duri $D$. setosum seperti itu adalah hal yang biasa. Karena duri tersebut hanyalah sebagai alat pertahanan tubuh $D$. setosum dari predator dan racunnya tidak mematikan. Bagi nelayan yang kesehariannya bersentuhan dengan berbagai aktivitas penangkapan landak laut $D$. Setosum, tertusuk duri landak laut adalah hal yang biasa. Namun demikian, bukan berarti nelayan lokal tidak berinovasi untuk menghindari racun landak laut yang masih saja terasa sakitnya ketika tertusuk duri $D$. setosum tersebut.

Beberapa alat tangkap tradisional yang digunakan oleh masyarakat nelayan di Pulau Tomia untuk menangkap landak laut adalah

1. Kayu bercabang

Kayu yang digunakan dalam proses penangkapan landak laut $D$. setosum adalah kayu bercabang yang berbentuk huruf $Y$ yang secara lokal dikenal dengan nama "kau pangga". Dengan bentuk itu, duri-duri landak laut dapat dengan mudah diangkat dari dalam perairan ke permukaan, karena duri landak laut tersanga di antara kedua cabang kayu. Adapun teknik pengoperasiannya adalah dengan mencungkil landak laut satu per satu dari kumpulan atau gerombolan landak laut $D$. setosum. Setalah duri duri landak laut terapit di antara dua cabang kayu, selanjutnya diangkat dan ke permukaan dan disimpan ke dalam perahu.

\section{Parang}

Teknik penangkapan landak laut dengan landak laut diawali dengan menarik satu persatu keluar landak laut dari gerombolan atau kumpulan komunitasnya. Selanjutnya, dilakukan pemotongan duri-duri pada landak laut $D$. setosum.

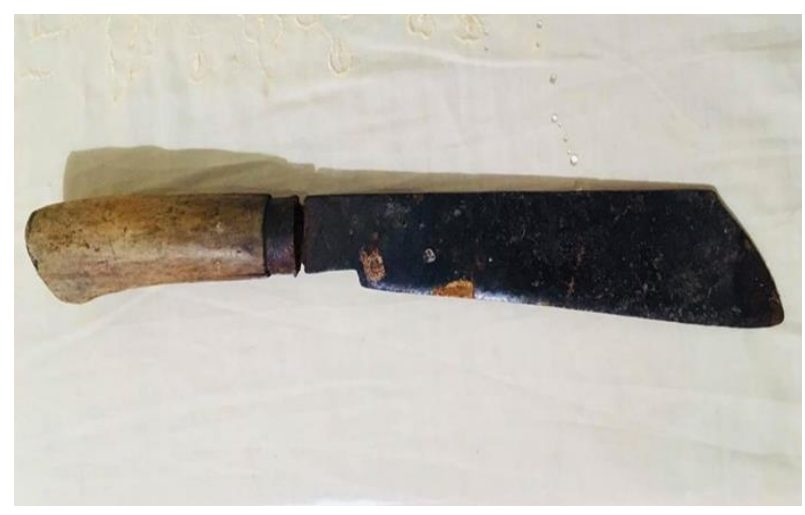

Bila duri jalan dan duri beracunnya sudah terpotong, lalu kemudian diangkat dan dimasukkan ke dalam perahu atau ember. Penggunaan parang ini umumnya digunakan oleh nelayan rekreasi untuk tujuan konsumsi saja pada saat air laut surut.

\section{Tanggo}

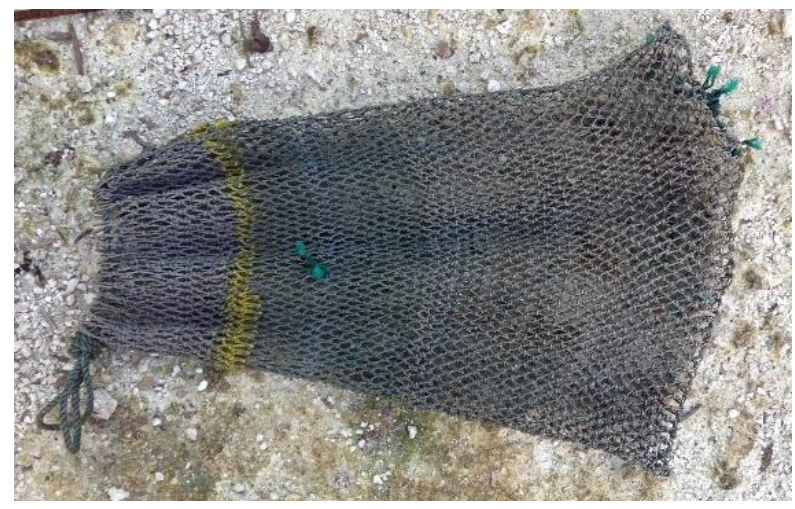

Tanggo terbuat dari jaring nilon yang digunakan sebagai salah satu alat dalam proses penangkapan landak laut. Tanggo dioperasikan 
dengan cara dicelupkan ke dalam laut hingga tenggelam. Lalu kemudian satu persatu landak laut dimasukkan ke dalam tanggo hingga penuh.

Lalu kemudian diangkat ke permukaan. Adapun alat bantu yang digunakan oleh nelayan untuk menggiring masuk tangkapan landak laut ke dalam tanggo adalah kayu panjang. Dengan demikian, tangan tidak tersusuk oleh duri landak laut.

Penangkapan landak laut dengan menggunakan tanggo umunya dioperasikan pada saat air laut pasang ketika nelayan sulit untuk menjangkaunya dengan berjalan kaki. pada saat air laut pasang dengan kedalaman 1 sampai dengan 2 meter. Tanggo merupakan alat yang paling efektif

\section{Keranjang}

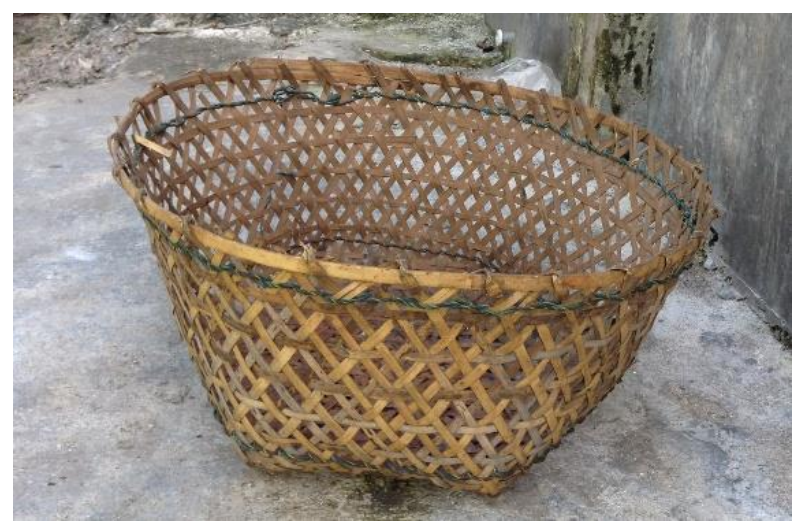

Keranjang (gambar di atas) digunakan sebagai alat untuk menangkap landak laut. Keranjang mudah dimasukkan atau ditenggelamkan ke dalam air karena memiliki banyak pori lubang. Sehingga mudah dioperasikan dalam air.

Selain itu, keranjang ini juga kerap digunakan sebagai alat untuk menggundulkan duri landak laut. Adapun cara untuk menggundulkan duri jalan dan duri bisa landak laut adalah dengan memasukkan landak laut $D$. setosum ke dalam keranjang sekitar 5-10 ekor, lalu diayak diayak dalam air sampai terlihat gundul .

\section{Serok}

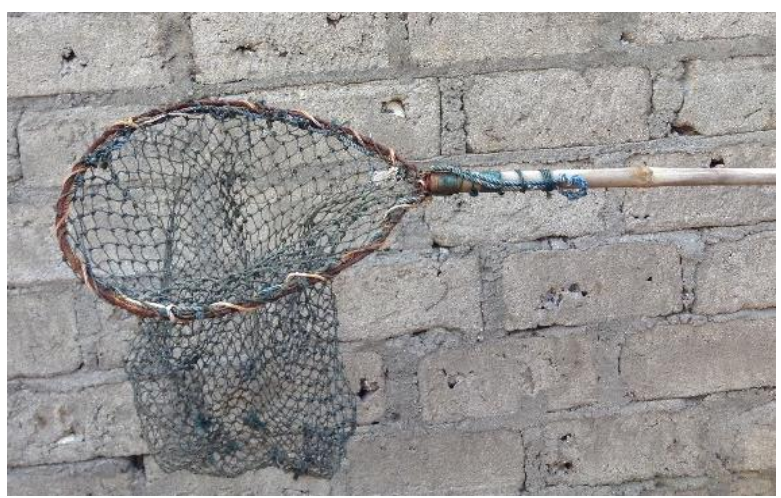

Serok ini digunakan untuk mengangkat landak laut ke perahu. Pengoperasian serok seperti ini umumnya dilakukan ketika ketinggian air laut adalah setinggi lutut atau perut. Untuk memudahkan nelayan melakukan penangkapan landak laut $D$. setosum. Maka digunakanlah serok ini untuk mengangkat landak laut dari dalam air ke dalam perahu.

\section{Conclusion}

Penangkapan landak laut $D$. setosum di Wakatobi telah lama dilakukan. Telurnya dikonsumsi dalam keadaan segar. Dari hasil survei penulis terhadap jenis-jenis alat tangkap tradisional yang digunakan dalam penangkapan landak laut, Ditemukan ada lima jenis alat tangkap yang umum digunakan oleh nelayan landak laut di Pulau Tomia, Kabupaten Wakatobi yaitu: kayu bercabang, parang, tanggo, keranjang, dan serok. 


\section{References}

Aprilia, H. A., Pringgenies, D., \& Yudiati, E. (2012). Uji Toksisitas Ekstrak Kloroform Cangkang dan Duri Landak Laut (Diadema setosum) Terhadap Mortalitas Nauplius Artemia sp. Ournal of Marine Research, 1(1), 75-83. https://doi.org/10.14710/jmr.v1i1.890

Baruadi, A. S. R., \& Nane, L. (2020). Edukasi Pemanfaatan Bulu-Babi (Sea Urchin) Melalui Budi Daya Keramba Jaring Apung. Jurdimas Royal, 3(2), 169-174. https://doi.org/10.33330/jurdimas.v3i2.666

Lubis, S. A., Purnama, A. A., \& Yolanda, R. (2017). Spesies Bulu Babi (Echinoidea) di Perairan Pulau Panjang Kabupaten Bangka Tengah Provinsi Bangka Belitung. Jurnal IImiah Mahasiswa FKIP Prodi Biologi, 3(1).

Nane, L. (2019a). Efisiensi Mesin Teknologi Sapurata Dalam Mengoptimalisasi Produksi Inovasi Pangan Kukure Di Pulau Barrang Lompo, Makassar. https://doi.org/10.31230/osf.io/q8spg

Nane, L. (2019b). Sea Urchin Sustainability Studies Based on Dimension Biology, Ecology and Technology at Around of Tolandono Island and Sawa Island at Wakatobi Conservation Area. https://doi.org/10.31230/osf.io/4whz6

Nane, L. (2019c). Studi Keberlanjutan Perikanan Landak Laut Berdasarkan Dimensi Biologi, Ekologi Dan Teknologi Di Sekitar Pulau Tolandono Dan Pulausawa Kawasan Konservasi Wakatobi [Skripsi, Universitas Hasanuddin]. https://marxiv.org/9zdvr/

Nane, L. (2020). Pemanfaatan Telur Landak Laut Diadema setosum di Pulau Taliabu, Maluku Utara, Indonesia. https://doi.org/10.31219/osf.io/kmtuv

Nane, L., \& Paramata, A. R. (2020). Impact of Overfishing on Density and Test-Diameter Size of the Sea Urchin Tripneustes gratilla at Wakatobi Archipelago, South-Eastern Sulawesi, Indonesia. ILMU KELAUTAN: Indonesian Journal of Marine Sciences, 25(2), 53-56. https://doi.org/10.14710/ik.ijms.25.2.53-56

Noviana, N. P. E., Julyantoro, P. G. S., \& Pebriani, D. A. A. (2019). Distribusi dan Kelimpahan Bulu Babi (Echinoidea) di Perairan Pulau Pasir Putih, Desa Sumberkima, Buleleng, Bali. Current Trends In Aquatic Science, 2(1), 21-28.

Sukreni, S., Ibrahim, M. N., \& Isamu, K. T. (2018). Pengaruh Metode Penanganan Awal Yang Berbeda Terhadap Kualitas Gonad Landak Laut (Diadema Setosum). Jurnal Fish Protection, 1(1), 17-25. 